\title{
Neurorozwojowy wymiar gestu wskazywania palcem - rozwój i stymulacja
}

Neurodevelopmental dimension of the pointing gesture - significance and therapy

Słowa kluczowe: gest wskazywania palcem, rewolucja dziewiątego miesiąca, rozwój dziecka, stymulacja

Keywords: the pointing gesture, revolution of the ninth month, child development, stimulation

\section{Wprowadzenie}

Późna diagnostyka zaburzeń rozwoju indukowana jest częstokroć nieznajomością norm i praw rządzących rozwojem neurotypowym. Nieskuteczna terapia wynika natomiast najczęściej z braku świadomości korelacji pomiędzy językiem, poszczególnymi funkcjami poznawczymi oraz sprawnościami, na przykład motorycznymi. Przyglądając się podczas wieloletniej pracy terapeutycznej i diagnostycznej dzieciom, których trajektoria rozwoju przebiega neurotypowo oraz dzieciom z zaburzeniami rozwoju, nie sposób nie zauważyć pierwszych symptomów nieprawidłowości, które na wczesnych etapach życia objawiają się zazwyczaj brakiem sprawności, nie zaś zachowaniami naddatkowymi. Dostępna literatura przedmiotu, zarówno polsko-, jak i obcojęzyczna, wnikliwie referuje badania, które stanowić powinny kanwę dla planowania postępowania rewalidacyjnego w przypadku wystąpienia choćby najmniejszych zakłóceń rozwoju. Co więcej, wdrożenie oddziaływań terapeutycznych musi mieć miejsce jak najwcześniej, istnieje wówczas realna szansa na zniwelowanie nieprawidłowości.

\footnotetext{
* Uniwersytet Pedagogiczny w Krakowie, Instytut Filologii Polskiej, Katedra Logopedii i Zaburzeń Rozwoju, ul. Podchorążych 2, 30-084 Kraków, e-mail: anna.siudak@up.krakow.pl, ORCID: https:// orcid.org/0000-0002-1986-9078.

* Uniwersytet Pedagogiczny w Krakowie, Instytut Filologii Polskiej, Katedra Logopedii i Zaburzeń Rozwoju, ul Podchorążych 2, 30-084 Kraków, e-mail: ewa.bielenda-mazur@up.krakow.pl, ORCID: https://orcid.org/0000-0001-6206-7516.
} 
Niezwykle ważne jest rozpowszechnianie informacji na temat stymulacji i terapii dziecka, pojmowanej jako zespół usystematyzowanych oddziaływań, mających na celu wywołanie określonych umiejętności. Zarówno diagnoza, jak i terapia muszą odwoływać się do porządku nabywania sprawności, opartego na modelu rozwojowym. Jedynie odtworzenie etapów ujawniających się w rozwoju normatywnym umożliwia właściwe ukierunkowanie zaburzonego rozwoju. Właśnie „zidentyfikowanie wcześniejszych predyktorów późniejszej diagnozy jest istotne dla wczesnej interwencji" [Johnson, de Haan, 2018, s. 66; por. Korendo, Bielenda, 2018], umożliwia bowiem rozpoczęcie oddziaływań terapeutycznych, zanim dojdzie do spotęgowania cech rozwoju zaburzonego przez patologiczne interakcje ze środowiskiem, a w konsekwencji zmienia trajektorię rozwoju.

\section{Gest wskazywania palcem jako zdobycz rewolucji dziewiątego miesiąca}

Jedną z istotnych diagnostycznie umiejętności pojawiających się w wieku niemowlęcym jest komunikacyjny gest wskazywania palcem (GWP). Bazuje on na wspólnym zaangażowaniu i zdolności podążania za uwagą i zachowaniem innej osoby. Najczęstsza kolejność wyłaniania się wspomnianych umiejętności przebiega następująco [zob. Bielenda-Mazur, Siudak, 2019]:

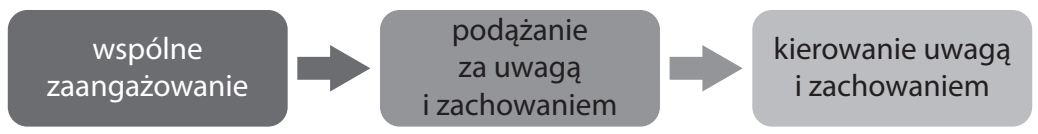

Rysunek 1. Społeczne podstawy kształtowania się gestu wskazywania palcem Źródło: opracowanie własne na podstawie Tomasello, 2002, s. 91.

Agnieszka Lasota, powołując się na liczne badania i taksonomie dotyczące rodzajów gestykulacji we wczesnym dzieciństwie [zob. Lasota, 2010; 2015], prezentuje typologię, w myśl której gesty dziecięce podzielić można na deiktyczne i reprezentujące. W zakresie gestów deiktycznych (wskazujących) wyróżnia gesty wskazywania (palcem, ręką), pokazywania przedmiotów, podawania ich oraz gesty służące upominaniu się o działanie. W rozwoju neurotypowym ujawniają się one między 9. a 13. miesiącem życia [por. Cieszyńska-Rożek, 2013]. Charakter gestów zmienia się w toku rozwoju: w początkowej fazie (9. miesiąc) występują one jedynie w wersji protoimperatywnej (nakazowej) - są nastawione na osiągnięcie celu - na przykład posiadania przedmiotu, nakłonienia rodzica do podania obiektu, wykonania określonego działania. Około 12. miesiąca życia pojawia się gest protodeklaratywny, który jest swoistym komentowaniem rzeczywistości - nastawiony na nakłonienie odbiorcy do zwrócenia uwagi na jej element. Lasota [2010; 2015] wyróżnia gesty imperatywne skierowane na przedmiot (wskazywanie przedmiotu, który dziecko 
chce otrzymać) i skierowane na działanie (podniesienie rąk, by rodzic podniósł dziecko, stukanie ręką o krzesło, by rodzic na nim usiadł). Gesty deklaratywne dzieli zaś na informacyjne (dziecko chce, by dorosły dowiedział się, czym ono się interesuje) i ekspresywne, empatyczne (dziecko chce, by dorosły dzielił z nim emocje związane z przedmiotami, sytuacjami i działaniami) oraz gesty pytające (dziecko domaga się komentarza).

Oprócz gestykulacji deiktycznej w rozwoju pojawia się również gestykulacja reprezentująca (symboliczna, odniesieniowa) wyrażona w postaci układów ruchów rąk, ciała, specyficznej mimiki, do których przywiązane są znaczenia. Pojawia się ona po 14. miesiącu życia i jest uwarunkowana kulturowo. Składają się na nią gesty prezentujące (imitujące) działanie (np. poruszanie rękami przypominające lecący samolot, ruch podczas pływania) oraz gesty konwencjonalne (np. zaprzeczający i potakujący ruch głowy) [Lasota, 2015].

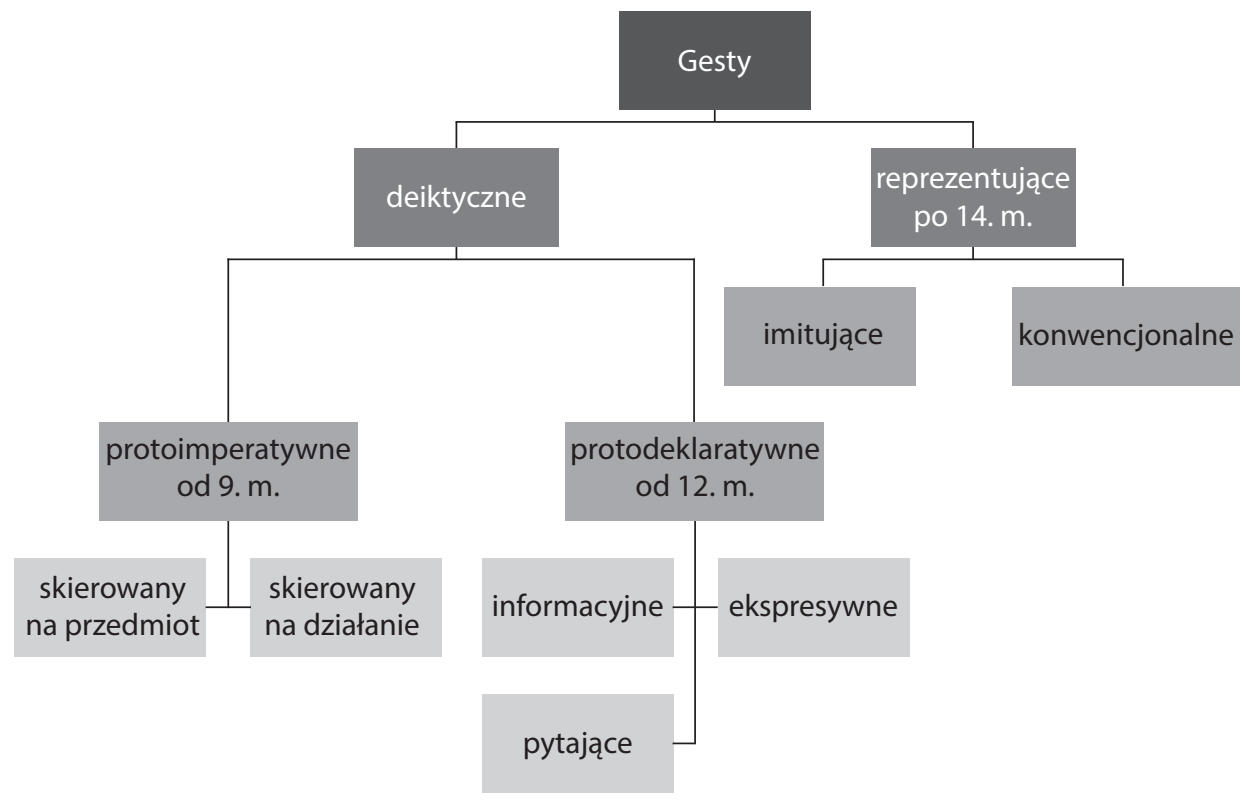

Rysunek 2. Gesty w ontogenezie

Źródło: opracowanie własne na podstawie Lasota, 2010; 2015.

Pojawiające się w komunikacji dziecka z otoczeniem gesty są wynikiem rozwoju motorycznego, poznawczego i społecznego [zob. Bielenda-Mazur, Siudak, 2019], podstawę umiejętności zarówno uczenia się języka, jak i opanowywania wyrafinowanych kompetencji społecznych stanowi zaś wyostrzona zdolność ludzka do koordynowania uwagi z partnerem społecznym [Mundy, Newell, 2007]. Wczesne przyswajanie języka opiera się na zdolności do wspólnej uwagi, dzięki której dziecko w nieustrukturalizowanych sytuacjach łączy formę akustyczną (słowo) z jej desygnatem (obiektem). 
Z badań wynika, że częste dzielenie wspólnej uwagi, w znacznej mierze inicjowane przez rodziców, przyczynia się do szybszego przyswajania języka [zob. Białecka-Pikul, Stępień-Nycz, Karwala, 2014], dziecko szybciej przyswaja zaś nazwy przedmiotów, którymi się zainteresowało, niż te, którymi próbuje zainteresować je dorosły ${ }^{1}$.

\section{Konsekwencje braku wystąpienia GWP}

Literatura przedmiotu i doświadczenia kliniczne wskazują, że GWP i pole wspólnej uwagi są bardzo istotnymi markerami rozwoju. Komunikacyjny gest wskazywania palcem zwykle samoistnie nie pojawia się u dzieci autystycznych, w przypadku osób z zespołem Aspergera występuje najczęściej jedynie gest protoimperatywny, brak natomiast gestu protodeklaratywnego [por. Baron-Cohen, 1989; Charman, 2003; Korendo, 2013; Watson i wsp., 2013]. Badania Allison Bean Ellawadi i Susan Ellis Weismer z 2014 roku wykazały, że większość dzieci z autyzmem kierowała swoją uwagę i wskazywała obiekty palcem (bez nawiązywania pola wspólnej uwagi z dorosłym) nawet wtedy, gdy zostawała sama w pomieszczeniu (gest point). U części tych dzieci nie występowały natomiast gesty o charakterze rozkazującym/nakazowym (gest give) ani oznajmująco-pytającym (gest show), za pomocą których dziecko zwraca się do dorosłego z pytaniem o obiekt lub chęcią pokazania mu obiektu [Bean Ellawadi, Ellis Weismer, 2014, s. 524-534]. Ponadto badania Donny Thal i Stacy Tobias wykazały, że dzieci o niższych kompetencjach językowych używały mniej gestów, a gesty w ontogenezie pojawiły się u nich później [za: Lasota, 2010]. Co więcej, ilość czasu spędzanego przez matkę i dziecko we wspólnym zaangażowaniu była powiązana z wczesnymi umiejętnościami komunikacji przedwerbalnej i werbalnej. Istotny dla przesłanek terapeutycznych wydaje się również fakt, iż zakres, w jakim wypowiedzi matki odnosiły się do tego, na czym w danym momencie dziecko skupiło uwagę, był predyktorem rozwoju językowego dziecka [Carpenter, Nagell, Tomasello za Białecka-Pikul, Stępień-Nycz, Karwala, 2014].

Zdaniem Michaela Tomasella [2002] występowanie u większości spośród badanych dzieci pomiędzy 9. a 12. miesiącem życia omawianych umiejętności w sposób zsynchronizowany i skorelowany świadczy o tym, że rewolucja dziewiątego miesiąca polega na pojawieniu się pierwszych przejawów kompetencji komunikacyjnej, wyrażającej się w rozumieniu przez niemowlęta innych osób jako intencjonalnych sprawców działań.

1 Ważne jest zatem nie tylko kierowanie uwagi dziecka w stronę obiektów, na które patrzy dorosły, ale przede wszystkim podążanie za uwagą dziecka i nazywanie obiektów, na które ono patrzy. 


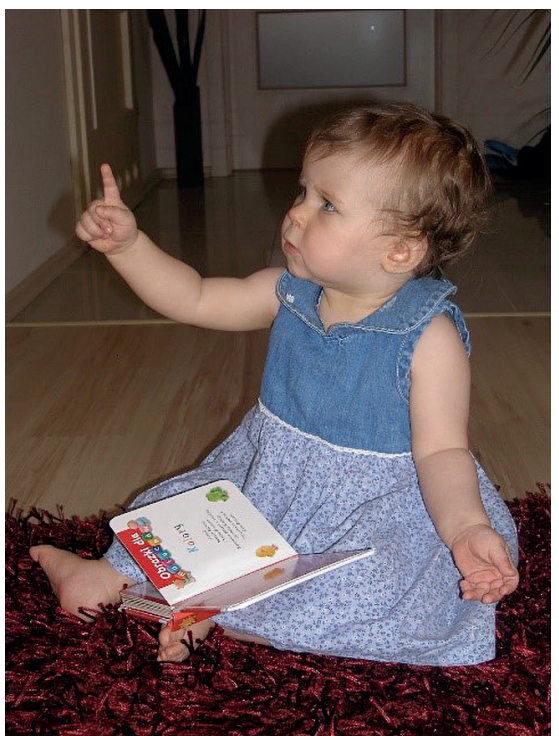

Fotografia 1. Intencja komunikacyjna wyrażona gestem

Źródło: archiwum własne.

\section{Model postępowania terapeutycznego w przypadku braku GWP}

Badania dzieci w wieku 9-18 miesięcy [Mundy, Newell, 2007] wykazały, że dzieci rozwijające się normatywnie prezentują wyższy poziom odpowiadania na wspólną uwagę i inicjowania wspólnej uwagi oraz inicjowania żądań niż dzieci z grupy ryzyka opóźnienia rozwojowego. Ponadto odpowiadanie na wspólną uwagę i jej inicjowanie w 12 . i 18. miesiącu „okazało się predyktorem poziomu rozwoju językowego w wieku 24 miesięcy" [Białecka-Pikul, Stępień-Nycz, Karwala, 2014, s. 55]. Liczne badania potwierdzają korelację pomiędzy zdolnością podążania za spojrzeniem i posługiwania się gestami a rozwojem językowym i społecznym na dalszych etapach [zob. Białecka-Pikul, Stępień-Nycz, Karwala, 2014]. Połączenie gestu i słowa (dziecko wskazuje na mamę i mówi mama) stanowi etap poprzedzający pojawienie się istotnej umiejętności - łączenia dwóch słów w wypowiedzi, która inicjuje rozwój podsystemu syntaktycznego.

Powyższe spostrzeżenia muszą zatem skutkować oddziaływaniami terapeutycznymi w sytuacji zaburzenia, zagrożenia zaburzeniem bądź zakłócenia rozwoju. Mogą również stanowić element stymulacji dziecka rozwijającego się normatywnie. W oddziaływaniach tych można wyodrębnić następujące poziomy:

- poziom 1 - stymulacja motoryczna;

- poziom 2 - stymulacja poznawcza;

- poziom 3 - stymulacja językowa. 
Poziomy zwykle wzajemnie się przenikają, trudno bowiem wyobrazić sobie ćwiczenia motoryczne czy poznawcze pozbawione komentarzy werbalnych, dzięki którym dziecko budować będzie kompetencje językowe. Poziomy świadczą jedynie o przewadze umiejętności, które kształcimy podczas oddziaływań profilaktycznych czy terapeutycznych. Korelację poszczególnych etapów przedstawia Rysunek 3.

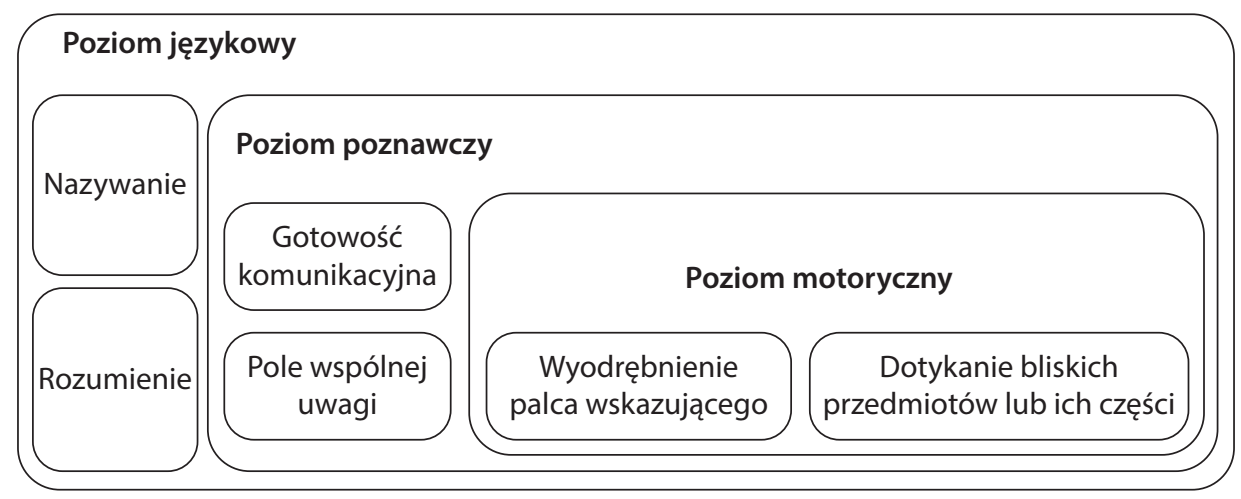

Rysunek 3. Gest wskazywania palcem jako akt komunikacji

Źródło: opracowania własne.

\section{Poziom 1. Stymulacja motoryczna - wyodrębnianie palca wskazującego}

Z neurobiologicznych badań wynika, że istnieją ścisłe powiązania lokalizacyjno-funkcjonalne pomiędzy ruchową a czuciową korą mózgową. Nie jest zatem możliwy rozwój funkcji ruchowych bez bodźców czuciowych. Z tego względu pierwsze starania o wyodrębnienie palca wskazującego niezbędnego do prawidłowego rozwoju GWP powinny zawierać stymulację wrażeń taktylnych ${ }^{2}$, takich jak:

- „czesanie” paluszka szczoteczką, łaskotanie/podrażnianie dłonią, pocieranie gryzaczkami, gąbkami, ściereczkami (ważne są różne faktury);

- naciskanie paluszkiem dziecka o blat stołu, kubek, zabawki z drewna, plastiku, pluszu i innych materiałów;

- dotykanie na zmianę paluszkiem przedmiotów chłodnych/twardych (np. płytek podłogowych, ściany) oraz ciepłych/miękkich (np. poduszka, ubrania);

- dotykanie małych przedmiotów, na przykład guziczków, grochu, okruszków chleba;

2 Wielu naukowców jest zgodnych, że to właśnie dotyk stał się bazą do kształtowania się pozostałych zmysłów [zob. Przezwański, 1959]. Jego znaczenie dla filogenetycznego rozwoju potwierdzają badania nad najbardziej prymitywnymi organizmami, donoszące, że reakcje na bodźce taktylne są wspólne u wszystkich zwierząt. Również badania nad prenatalnym rozwojem dzieci pokazują, że jest to modalność, która w rozwoju ontogenetycznym pojawia się jako pierwsza (jeszcze w pierwszym trymestrze ciąży) [zob. Przezwański, 1959; Siudak, 2019]. 
- wkładanie paluszka dziecka do pojemnika napełnionego plasteliną, piaskiem, suchym grochem, kaszą, żwirkiem itp. (ćwiczenia te wymagają obecności osoby dorosłej, należy uważać, by dziecko nie brało drobnych elementów do buzi);

- wkładanie paluszka w produkty spożywcze (do ciasta, chleba, kaszki, wody, soczku) i pozwalanie dziecku na jego oblizywanie;

- przyklejanie na paznokieć dziecka naklejki lub pomalowanie go spożywczym barwnikiem (można włożyć paluszek do soku z malin, truskawek, jagód lub buraka);

- założenie na paluszek „czapeczki”, pacynki lub owinięcie wokół niego małej szmatki;

- założenie rękawiczki z wyciętą dziurką.

Równolegle warto utrwalać ruchowy wzorzec wyprostowanego palca wskazującego poprzez:

- zabawy paluszkowe typu: Sroczka kaszkę warzyła, Tu paluszek, tu paluszek, Gdy się palce spotykaja, Auto do myjni przyjechało, bo się umyć ładnie chciało (fot. 2);

- zabawy typu:TIK- dotykanie własnym palcem wskazującym paluszka dziecka (fot. 3);

- dotykanie własnego paluszka w lustrze (wariant zabawy TIK) (fot. 4);

- dotykanie paluszkiem pozostałych paluszków (fot. 5);

- umożliwienie dziecku wkładania paluszka do otworków, kółeczek, dziurek (fot. 6);

- przygotowanie dziecku dziurek zrobionych w tekturkach, ilustracjach, książeczkach (fot. 7);

- pokazywanie dziecku ruchomych części zabawek, na przykład kółek w samochodach, części ciała itp. (fot. 8);

- pokazywanie dziecku zabawek z guziczkami do naciskania, na przykład zabawkowych pilotów, telefonów (fot. 9);

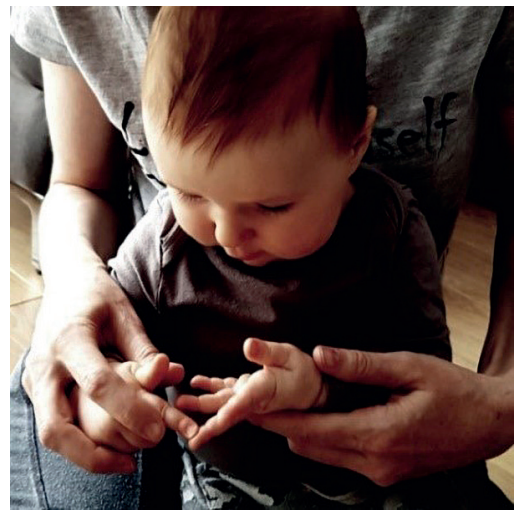

Fotografia 2. Zabawy paluszkowe

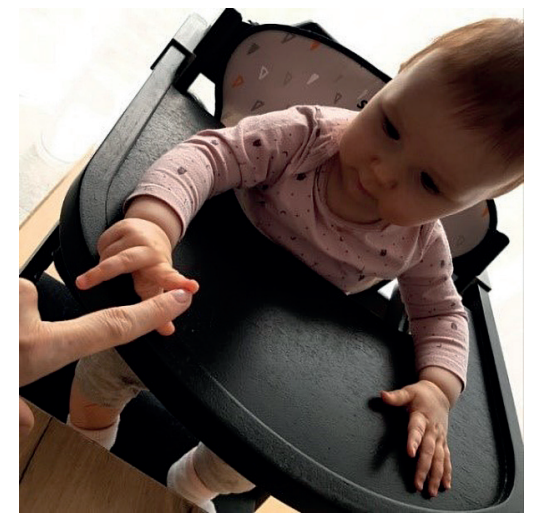

Fotografia 3. Zabawa typu TIK

Źródło: archiwum własne. 


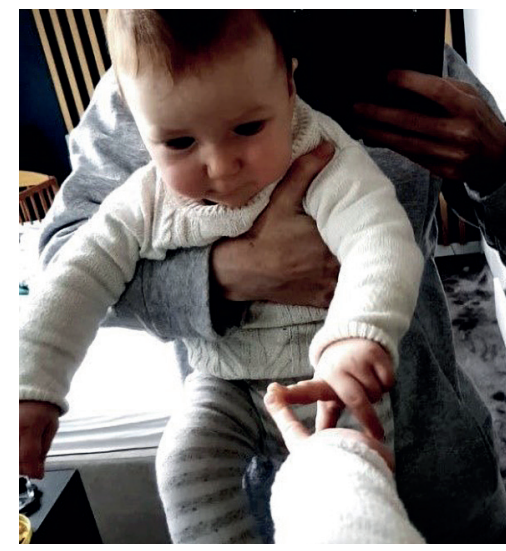

Fotografia 4. Zabawy z własnym odbiciem

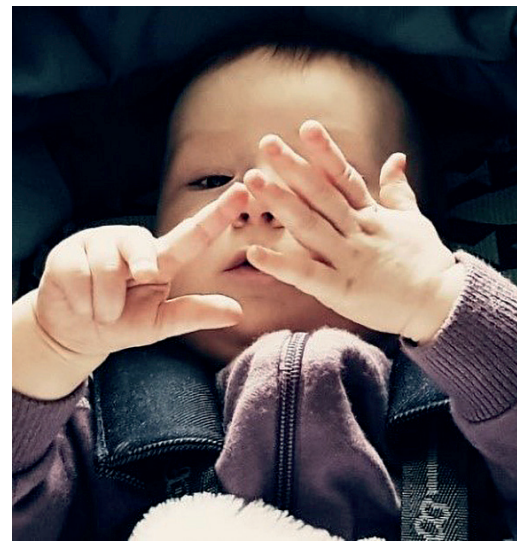

Fotografia 5. Zabawy z własnym ciałem Źródło: archiwum własne.

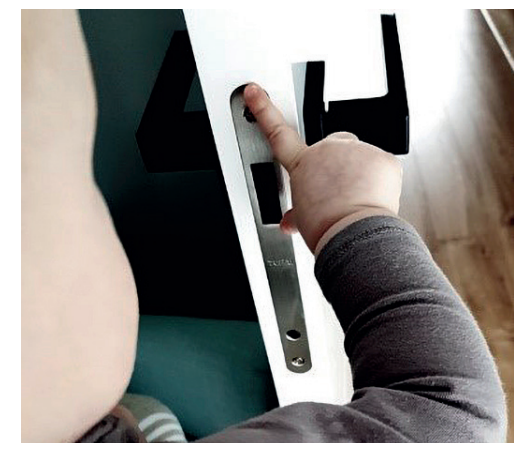

Fotografia 6. Dotykanie małych elementów

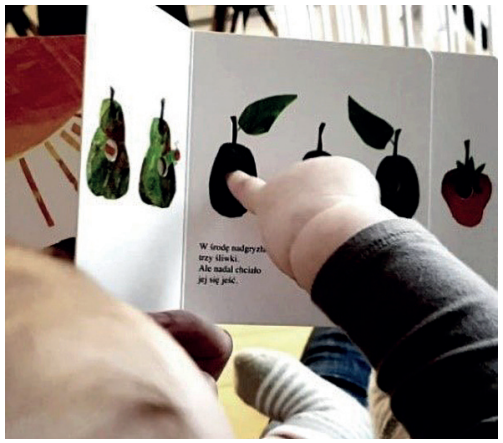

Fotografia 7. Wkładanie paluszka w otwory

Źródło: archiwum własne.

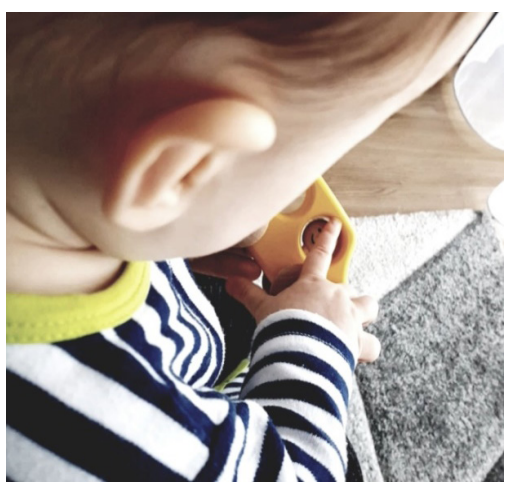

Fotografia 8. Dotykanie ruchomych elementów

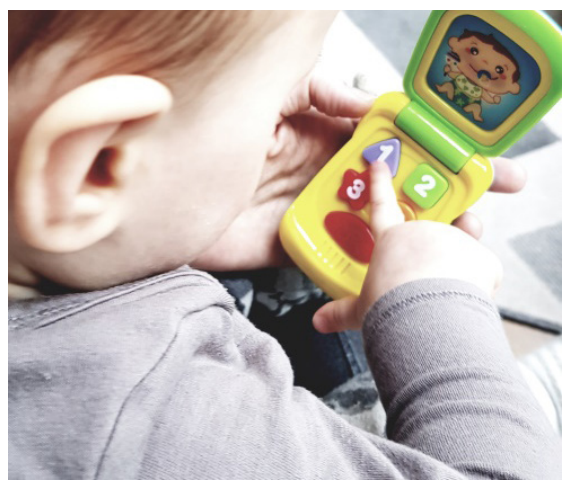

Fotografia 9. Naciskanie małych elementów 


\section{Poziom 2. Stymulacja poznawcza - pole wspólnej uwagi i gotowość komunikacyjna}

Pierwszym etapem kształtowania się pola wspólnej uwagi jest ukierunkowanie zainteresowania dziecka na przedmiot, na który patrzy dorosły. W tym celu należy zwracać uwagę dziecka na przedmioty będące w bliskim otoczeniu, mogące zainteresować niemowlę, poprzez bodźce polisensoryczne: wykorzystanie światła, dźwięku, ruchu i jednoczesne pokazywanie palcem. Ćwiczenia te stanowią podstawę do stymulacji językowej (budują rozumienie), której omawiany trening nie powinien być pozbawiony. Tworzenie kontekstu, w którym dziecko będzie uczyło się znaczeń, jest istotnym etapem gotowości komunikacyjnej. Dzięki połączeniu umiejętności motorycznych i poznawczych dziecko zaczyna odkrywać znaczenia, nabywać słownictwo, rozumieć polecenia (początkowo podparte gestami, a na dalszym etapie bez ich udziału) oraz komunikować swoje potrzeby za pomocą prymarnych elementów językowych. Podczas ćwiczeń najpierw wykonujemy działanie (np. poruszamy przedmiotem, oświetlamy go), potem wskazujemy obiekt swoim palcem, a następnie palcem dziecka - procedura powtarza się przy każdym ćwiczeniu. Budowanie pola wspólnej uwagi jest jednocześnie kształceniem zdolności podążania za gestem osoby dorosłej oraz kierowania jej uwagą. Aby niemowlę zdobyło podstawy niezbędne do tych umiejętności, $w$ codziennej zabawie można wykorzystać:

- pokazywanie paluszkiem $\mathrm{z}$ równoczesnym nazywaniem obrazków w książeczkach lub ich fragmentów;

- układanie czerwonego kółka na ilustracji w książkach w celu zwrócenia uwagi na szczegóły;

- stukanie w elementy zabawek lub kartki tekturowych książeczek, z jednoczesnym nazywaniem: 'piłka' bam bam, 'auto' brum brum;

- skrobanie paznokciem elementów zabawek, na przykład oka misia, buzi lali, z jednoczesnym nazywaniem: oko!, buzia! (fot. 10);

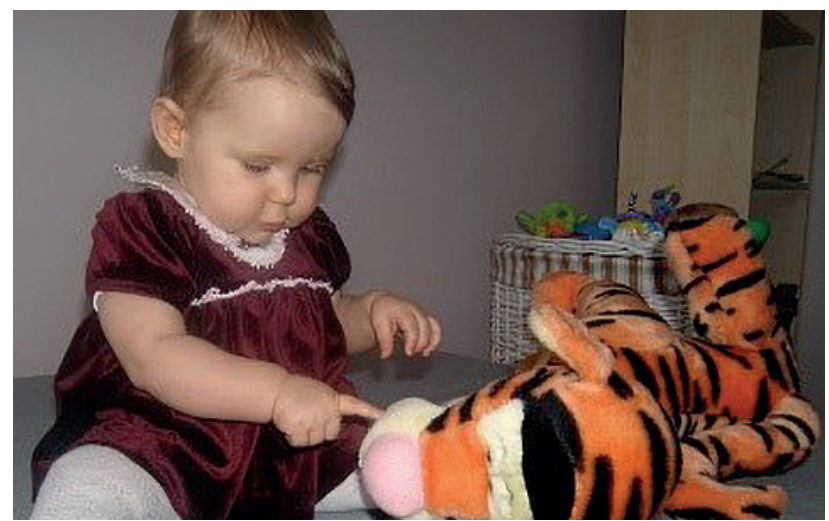

Fotografia 10. Wskazywanie małych elementów (oko, buzia, nos)

Źródło: archiwum własne. 
- zapalanie i gaszenie światła w celu skierowania uwagi dziecka na lampę, z jednoczesnym nazywaniem: $O$, lampa!; (fot. 11)

- wytwarzanie dźwięku lub ruchu w otoczeniu: poruszanie firanką, odsłanianie okna, naciskanie klamki, pukanie, głośne zamykanie drzwi szafy itp. i jednoczesne nazywanie przedmiotów: O, okno! drzwi! szafa!;

- wskazywanie małych, kontrastowych elementów w otoczeniu (fot. 12).

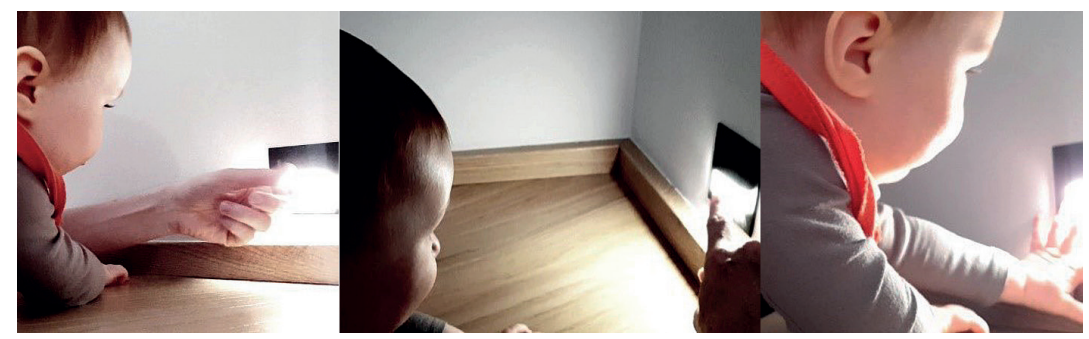

Fotografia 11. Wykorzystanie dźwięku, światła i ruchu w kształtowaniu pola wspólnej uwagi Źródło: archiwum własne.

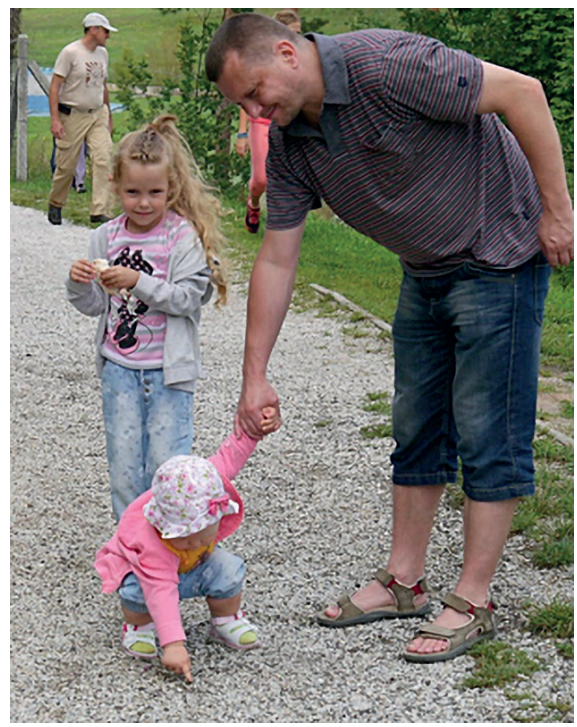

Fotografia 12. Wskazywanie bardzo małych elementów w otoczeniu (robaczek wśród kamyczków)

Źródło: archiwum własne.

W trakcie zabaw zaleca się stopniowe odsuwanie się od przedmiotu i zadawanie pytania (np. Gdzie (jest) lampa?, Gdzie (jest) okno?3). Świadomość, że paluszek może

$3 \mathrm{~W}$ przypadku dzieci z trudnościami rozwojowymi, zgodnie z zasadami programowania języka [zob. Orłowska-Popek, 2017; Bielenda-Mazur, Orłowska-Popek, 2019; Orłowska-Popek, Bielenda-Mazur, 2019], zaleca się używanie zredukowanych fraz (pozbawionych orzeczenia). Jednakże w sytuacji naturalnego nabywania języka możliwe jest stosowanie prostych zdań zawierających czasownik. 
wskazywać także przedmioty znajdujące się w dalszym otoczeniu, wymaga od dziecka myślenia symbolicznego, tj. rozumienia, iż może on być „przedłużeniem uwagi”. Umiejętność ta kształtuje się w późniejszym etapie, lecz można ją stymulować dodatkowo poprzez:

- zabawę w szukanie domowników - osoba trzymająca dziecko pyta: gdzie mama? (tata/babcia/dziadzio) i wskazuje ją palcem, gdy nazywana osoba w tym czasie woła dziecko, by zwrócić na siebie jego uwagę;

- wykorzystywanie naturalnych dźwięków w sytuacjach poza domem, na przykład zadawanie pytań na spacerze: Gdzie (piesek) HAU HAU?, Gdzie (kotek) MIAU MIAU?, Gdzie (samolot) U-U?, Gdzie (auto) BRUM BRUM?, i wskazywanie gestem źródła dźwięku;

- zwracanie uwagi na lampę, gdy jest zapalona;

- zwracanie uwagi na ludzi, drzewo, motyla i inne obiekty w ruchu wraz z pytaniem: Gdzie pan?, Gdzie dzieci?, Gdzie drzewo?, Gdzie motyl?.
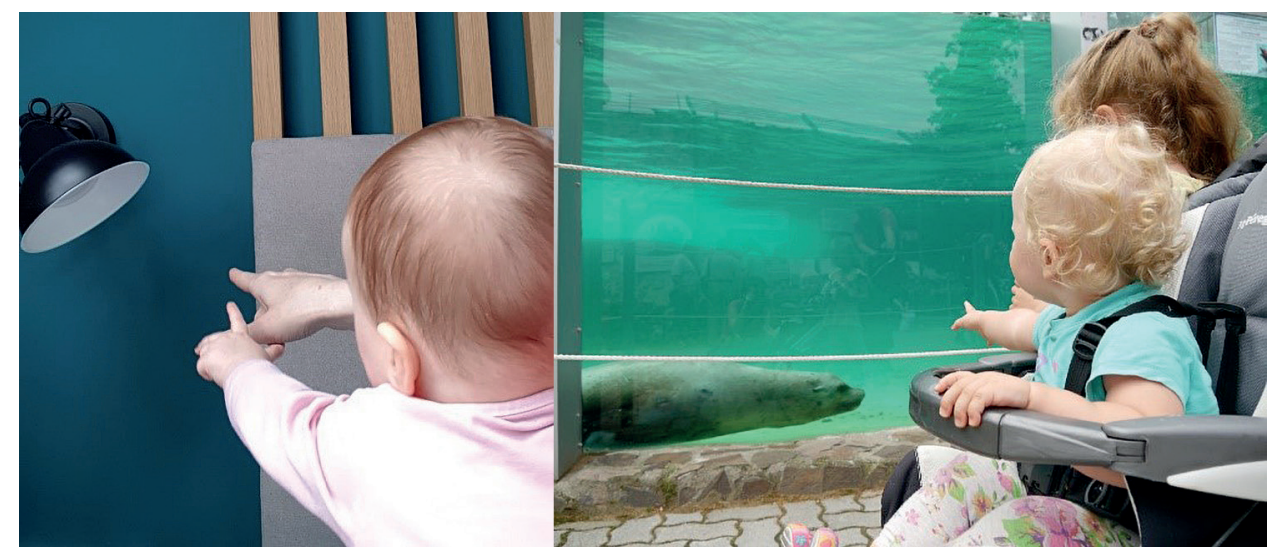

Fotografia 13. Wskazywanie obiektów oddalonych (położonych bliżej i dalej)

Źródło: archiwum własne.

Jeśli dziecko nie zwraca uwagi na prezentowane elementy, zwracamy jego głowę w stronę bodźca, który znajduje się w odległości około 50-70 cm lub przy pomocy drugiej osoby kierujemy uwagę dziecka poprzez dodatkowe bodźce dźwiękowe, świetlne lub ruchowe.

\section{Etap 3. Stymulacja językowa - rozumienie, nazywanie}

Ćwiczenia ukierunkowane wcześniej na zawiadywanie uwagą dziecka, budowanie słownika biernego są jednocześnie stymulacją audytywną, przygotowującą do pojawienia się pierwszych słów. Gest wskazywania będziemy więc ćwiczyć, kierując paluszkiem dziecka na elementy przez nas nazywane: mówimy mama i wskazujemy na mamę, następnie pytamy: Kto to? Mama! i palcem dziecka wskazujemy ją, czekając na werbalną reakcję dziecka (w przypadku braku podejmowania przez dziecko 
prób w nazwaniu obiektu powtarzamy czynność). W ten sposób wskazujemy i nazywamy osoby z najbliższego otoczenia, jednocześnie nazywając je w sposób najprostszy, starając się często korzystać z wyrazów, których forma oparta jest na strukturze gaworzenia samonaśladowczego, tj. zbudowana $\mathrm{z}$ reduplikowanej sylaby otwartej: mama, tata, baba, dziadzia, bądź z dwóch sylab otwartych. Nie używamy mowy niań (zawierającej infantylizację fonetyczną). Mówimy, wykorzystując parametry mowy matczynej, tj. nieco wyższym tonem, głośniej, wolnej oraz z nieco przesadną intonacją [zob. Milewski, 2004; Eliot, 2010]. Warto także często podążać za uwagą dziecka, wskazywać i nazywać obiekty, na które ono patrzy. Zestaw zabaw wspomagających językowe umiejętności powinien obejmować najpierw gesty protoimperatywne - skierowane na przedmiot i na działanie, później gesty protodeklaratywne - informacyjne i ekspresywne. Może on przyjąć następującą formę:

- zadawania pytania o obiekt, który dziecko lubi i z dużym prawdopodobieństwem chciałoby otrzymać, na przykład przed ulubionym posiłkiem, który jest już przygotowany, w zasięgu wzroku dziecka, pytamy: Gdzie am, am?, Gdzie piciu? i wskazujemy, mówiąc $t u$, gdy wskazujemy palcem dziecka, mówimy daj i podajemy mu obiekt; podobnie postępujemy z ulubioną zabawką dziecka, gdy na nią spogląda;

- wskazywania i nazywania przedmiotu, na którym dziecko samo skupia uwagę;

- zadawania pytań dziecku: Gdzie (jest) piłka?, Gdzie (jest) brum brum?, i udzielanie odpowiedzi połączonej z gestem wskazywania: Tu!, Tu (jest) piłka!, Tu (jest) brum brum!;

- skrobanie paznokciem elementów zabawek, na przykład oka misia, buzi lali, z jednoczesnym pytaniem: Gdzie (jest) oko?, Gdzie (jest) buzia? i natychmiastową odpowiedzią połączoną z gestem wskazywania: Tu!, Tu (jest) oko!, Tu (jest) buzia!;

- zapalanie i gaszenie światła w celu skierowania uwagi dziecka na lampę, z jednoczesnym pytaniem: Gdzie (jest) lampa? i natychmiastową odpowiedzią połączoną z gestem wskazywania: Tu!, Tu (jest) lampa!;

- wytwarzanie dźwięku lub ruchu w otoczeniu: poruszanie firanką, odsłanianie okna (Gdzie (jest) okno?), naciskanie klamki, pukanie (Gdzie (sq) drzwi?), głośne zamykanie drzwi szafy (Gdzie (jest) szafa?) itp. i wskazywanie na obiekty $\mathrm{z}$ równoczesną odpowiedzią;

- pokazywanie dwóch elementów identycznych i ich nazywanie, np. tu oko i tu oko!;

- pokazywanie dwóch elementów odmiennych i ich nazywanie, np. tu oko, a tu nos!.

Naturalną konsekwencją omawianych powyżej ćwiczeń jest próba samodzielnego nazywania przez dziecko osób i obiektów z otoczenia. Programowanie stałych struktur językowych (powtarzające się Gdzie jest...?, Tu jest...!, Gdzie sa...?, Tu sq...!) przyzwyczaja dziecko do stałej korelacji pytanie $\rightarrow$ odpowiedź, a zadawanie pytań (Kto 
to?, Co to?) buduje konotacje, w których imperatywem staje się udzielenie odpowiedzi (np. Mama!, Lampa!, Brum brum!). Utrwalone struktury wypowiedzi złożonych z pytań i odpowiedzi (ważnym elementem jest tu intonacja) będą zatem pobudzać dziecko do samodzielnych realizacji, a przez to kształtować się będzie jego zdolność do werbalnej komunikacji.

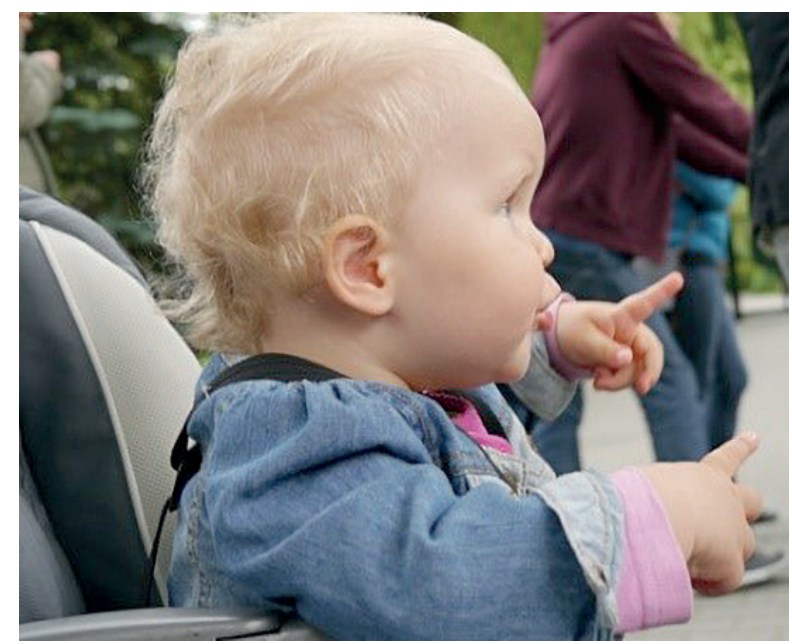

Fotografia 14. Gest wskazywania palcem (właściwie oboma palcami wskazującymi naraz) towarzyszący nazywaniu obiektów w otoczeniu

Źródło: archiwum własne.

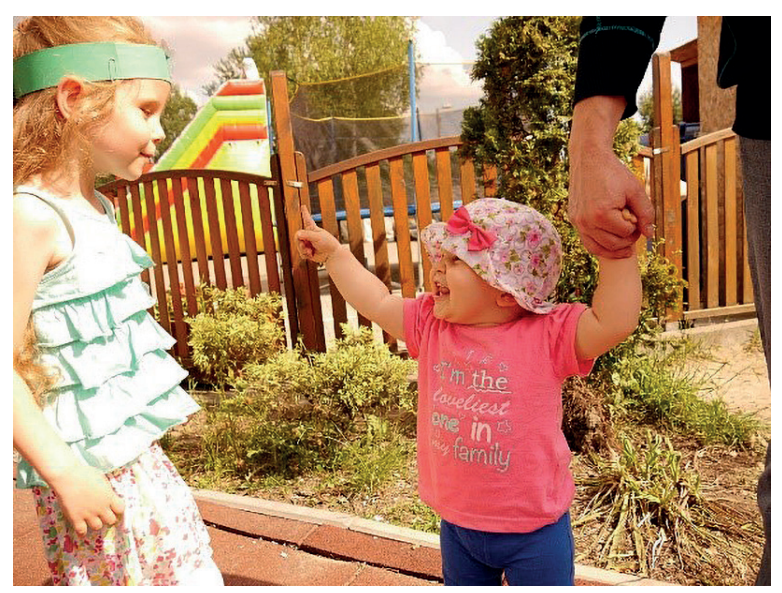

Fotografia 15. Gest ekspresywny

Źródło: archiwum własne. 


\section{Podsumowanie}

Obserwacje dzieci rozwijających się normatywnie dowodzą jednoznacznie, że gest wskazywania palcem jest koniecznym, oczekiwanym rozwojowo substratem komunikacji werbalnej. U dzieci prezentujących atypowy rozwój zauważa się brak lub opóźnienie pojawienia się GWP, co może świadczyć o braku gotowości komunikacyjnej. Tymczasem stanowi on ważny marker rozwojowy, niezbędny, by dziecko prezentujące rozwój atypowy, dostrzegło moc sprawczą komunikacji, początkowo niewerbalnej, a z czasem werbalnej. By także mogło budować język, naśladować i kooperować, czyli korzystać z pełni dobrodziejstw uczenia się społecznego, charakterystycznego dla gatunku ludzkiego. Pojawiający się samoistnie lub wywołany w toku terapii gest wskazywania palcem staje się sposobem komunikowania $\mathrm{z}$ otoczeniem do momentu, gdy zaczynają pojawiać się pierwsze słowa - wówczas przeistacza się $w$ gest pomocniczy dla gestu werbalnego. $Z$ czasem o wiele skuteczniejsza komunikacja werbalna wypiera w znacznej mierze komunikację gestową dziecka. Ta gotowość komunikacyjna, prezentowana przez zdrowe dzieci w różnych sytuacjach, najlepiej ilustruje piękno neurobiologii.

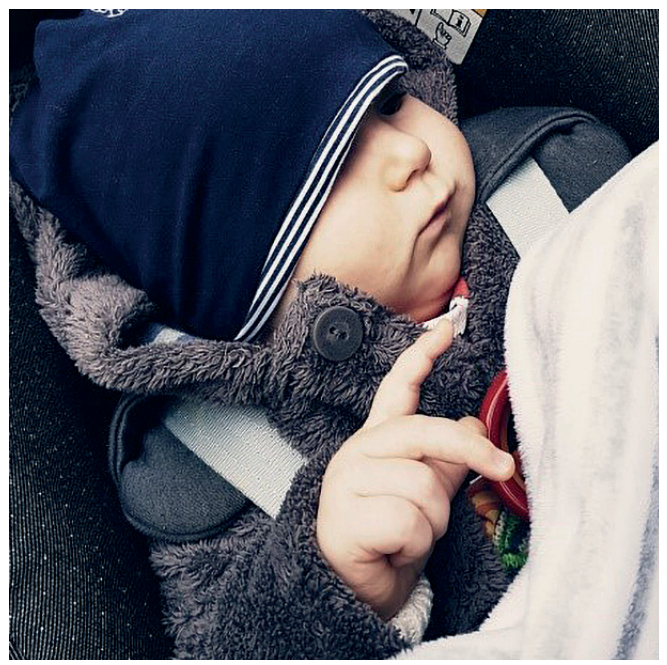

Fotografia 16. Gotowości komunikacyjna, czyli potęga neurobiologii i „zasypiający” gest wskazywania Źródło: archiwum własne. 
Literatura

Baron-Cohen S., 1989, The autistic child's theory of mind: A case of specific developmental delay, "Journal of Child Psychology and Psychiatry", t. 30, nr 2, s. 285-297.

Bean Ellawadi A., Ellis Weismer S., 2014, Assessing gestures in young children with autism spectrum disorders, „Journal of Speech, Language, and Hearing Research”, nr 57, s. 524-534.

Białecka-Pikul M., Stępień-Nycz M., Karwala M., 2014, Odkrywanie kompetencji komunikacyjnych niemowląt. Skala Wczesnej Komunikacji Społecznej jako przykład narzędzia pomiarowego, „Psychologia Rozwojowa”, t. 19, nr 3, s. 51-68.

Bielenda-Mazur E., Orłowska-Popek Z., 2019, Strategie programowania języka w przypadku różnych zaburzeń komunikacji, [w:] H. Pawłowska-Jaroń, E. Bielenda-Mazur, A. Siudak (red.), Nowa Logopedia, t. 8: Wyzwania terapii logopedycznej, Kraków: Collegium Columbinum, s. 43-52.

Bielenda-Mazur E., Siudak A., 2019, Gest wskazywania palcem w świetle doniesień neurobiologicznych, „Logopaedica Lodziensia” 2019, nr 3, s. 21-30.

Charman T., 2003, Why is joint attention a pivotal skill in autism?, „Philosophical Transactions of the Royal Society of London”, series B: „Biological Sciences”, t. 358, nr 1430, s. 315-324.

Cieszyńska-Rożek J., 2013, Metoda krakowska wobec zaburzeń rozwoju dzieci. Z perspektywy fenomenologii, neurobiologii i językoznawstwa, Kraków: Centrum Metody Krakowskiej.

Eliot L., 2010, Co tam się dzieje? Jak rozwija się mózg i umysł w pierwszych pięciu latach życia, Warszawa: Wydawnictwo Media Rodzina.

Johnson M.H., Haan M. de, 2018, Neurokognitywistyka rozwoju. Wprowadzenie, Gdańsk: Wydawnictwo Harmonia.

Korendo M., 2013, Językowa interpretacja świata w wypowiedziach osób z zespołem Aspergera, Kraków: Centrum Metody Krakowskiej.

Korendo M., Bielenda-Mazur E., 2018, Neurobiologiczne reguly diagnozy i terapii neurobiologicznej, [w:] B. Szołtysek (red.), Progres neonatologii a postawa terapeutów wczesnego wspomagania rozwoju, Tarnów: Wydawnictwo Tarnowskiej Szkoły Wyższej, s. 26-35.

Lasota A., 2010, Świat gestów i symboli w komunikacji dziecięcej, Kraków: Oficyna Wydawnicza Impuls.

Lasota A., 2015, Gestykulacja dziecięca, http://encyklopediadziecinstwa.pl/index.php/Gestykulacja _dziecięca (dostęp: 10.03.2020).

Milewski S., 2004, Mowa dorostych kierowana do niemowlat: studium fonostatystycznofonotaktyczne, Gdańsk: Wydawnictwo Uniwersytetu Gdańskiego.

Mundy P., Newell L., Attention, Joint Attention, and Social Cognition, „Current Direction in Psychological Science", November 2007, t. 16, nr 5, s. 269-274.

Orłowska-Popek Z., 2017, Programowanie języka w terapii logopedycznej na przykładzie rozwoju języka dzieci niestyszących, Kraków: Wydawnictwo Naukowe Uniwersytetu Pedagogicznego.

Orłowska-Popek Z., Bielenda-Mazur E., 2019, Programowanie języka - niezbędna technika w terapii logopedycznej, [w:] H. Pawłowska-Jaroń, E. Bielenda-Mazur, A. Siudak (red.), Nowa Logopedia, t. 8: Wyzwania terapii logopedycznej, Kraków: Collegium Columbinum, s. 33-42.

Przezwański R., 1959, Zjawiska dotykowe i wibracyjne. Wybrane problemy badawcze, „Zeszyty Problemowe Nauki Polskiej”, z. XVI: Kompensacja czynności narząów zmysłowych, Państwowe Zakłady Wydawnictw Szkolnych, Warszawa, s. 165-204.

Siudak A., 2019, Fizjologiczne i patologiczne aspekty inwolucji zmysłów - cz. 2: Dotyk, smak i węch, [w:] B. Kazek, J. Wojciechowska (red.), Zmysty w procesie starzenia, Warszawa: Wydawnictwo Uniwersytetu Warszawskiego, s. 185-208.

Tomasello M., 2002, Kulturowe źródła ludzkiego poznawania, Warszawa: Państwowy Instytut Wydawniczy.

Watson L.R., Crais E.R., Baranek G.T., Dykstra J.R., Wilson K.P., 2013, Communicative gesture use in infants with and without autism: A retrospective home video study, „American Journal of Speech-Language Pathology", t. 22, nr 1, s. 25-39. 


\section{Streszczenie}

Artykuł stanowi kontynuację rozważań autorek nad gestem wskazywania palcem (GWP) u niemowląt. Podstawy teoretyczne zawarte w tekście Gest wskazywania palcem wświetle doniesień neurobiologicznych zostały dopełnione o rozważania nad konsekwencjami braku GWP u dzieci oraz o ćwiczenia stymulujące, które zaprogramowano z uwzględnieniem trzech aspektów istotnych dla jego pojawienia się: stymulacji motorycznej, poznawczej oraz językowej. Przedstawiony autorski model oddziaływań terapeutycznych stanowi podstawę do budowania u dziecka zdolności komunikowania się - początkowo z wykorzystaniem gestu wskazywania, a następnie gestu werbalnego.

\section{Abstract}

The article is a continuation of the authors' discussion on the pointing gestures in infants. The theoretical bases enclosed in the text The neurodevelopmental dimension of the pointing gestures - review of reports were complemented with considerations of the consequences of the lack of the pointing gesture in children and stimulation exercises that were designed taking into account three aspects relevant to its emergence: motor, cognitive and linguistic stimulation. The presented model of therapeutic interactions is an indispensable basis for building a child's ability to communicate - initially using the pointing gesture and then - a verbal gesture. 